Industrial Health, 1976, 14, 67.

\title{
AVAILABILITY OF ACTIVITY RATIO OBTAINED FROM ACTIVITY OF 5-AMINOLEVULINATE HYDRO-LYASE IN HUMAN BLOOD BEFORE AND AFTER HEAT TREATMENT TO EVALUATE LEAD EXPOSURE
}

\author{
Momoko CHIBA, Akiko TASHIRO, Taichiro NISHIMA \\ and Masakazu KIKUCHI \\ Department of Hygiene, Juntendo University School of \\ Medicine, Hongo, Bunkyo-ku, Tokyo
}

(Received August 7, 1976)

\begin{abstract}
The activity of 5-aminolevulinate hydro-lyase (ALAD) in blood decreases in lead-exposed subjects. The activity of the hemolysed blood is restored by heat treatment $\left(60^{\circ} \mathrm{C}\right.$, for $\left.5 \mathrm{~min}\right)$ almost completely. A parameter of "activity ratio", dividing the enzyme activity before heat treatment by that after heat treatment, is proposed for evaluation of lead exposure, and this ratio was calculated in 167 human subjects, including those exposed to lead in work, lead concentration in their blood ranging 3.5 to $82 \mu \mathrm{g} / 100 \mathrm{~g}$ blood. Correlation of the ratio against blood lead concentration was higher than that of the ALAD activity itself. As there are, in addition, subjects with lower-than-normal ALAD activity values regardless of lead exposure, the ratio is available as an index to evaluate the extent of lead exposure.
\end{abstract}

In 1963, Lichtman and Feldman ${ }^{11}$ reported that the actviiy of 5 -aminolevulinate hydro-lyase ( $\delta$-aminolevulinic acid dehydrase, ALAD, EC 4.2.1.24) in blood was reduced by exposure of humans to lead. It is generally accepted that blood ALAD ac tivity decreases even when the organisms are exposed a low level of lead that will not give any clinical symptoms or signs, and that determination of the activity has a good reproducibility and specificity. Therefore, it is used as a sensitive index in medical examination for evaluating lead exposure. Bonsignore et al., ${ }^{2)}$ Vergnano et al., ${ }^{3)}$ and Candura et al. . $^{\prime}$ found and we also comfirmed ${ }^{5,6)}$ that the activity lowered by lead can be restored by heating the hemolysate before the activity assay. We proposed, therefore, to use the activity ratio as a new parameter which was calculated from the ALAD activity of blood with and without heat treatment, for evaluating the effecr of lead on organisms. This ratio shows a closer negative correlation with lead concentration in blood $(\mathrm{Pb}-\mathrm{B})$ rather than the activity of ALAD itself. This activity ratio was applied to 167 human subjects, ranging in lead concentration of 3.5 to $82 \mu \mathrm{g} / 100 \mathrm{~g}$ of blood and its usefulness was confirmed. 


\section{CHIBA, A, TASHIRO, T. NISHIMA \& M. KIKUCHI}

\section{Materials And Methods}

\section{Subjects}

Blood samples were obtained from the following three groups of subjects:

Group A (control). Thirty healthy persons (6 male and 5 female laboratory personnel, 15 male medical students, 2 male office workers, and 2 male factory workers). Their age ranged from 20 to 52 (mean 28) years. They were living in urban area, and had had no occupational or other contact with lead.

Group $B$ (moderate lead-exposure). This group consisted of 87 (including 4 female) printing factory workers (15 type-pickers, 29 typesetters, 28 printing press workers, 11 type foundry and stereotypers, and 4 engineering workers and storekeepers). Their mean age was 40 (range 18 to 63) years and mean working period was 21 (range 2 to 42) years. The atmospheric lead content was not higher than $0.54 \mathrm{mg} / \mathrm{m}^{3}$.

Group $C$ (high lead-exposure). Fifty male workers from a steel rope factory. They are engaged in annealing with molten lead or in bringing raw materials and unfinished products around the molten lead furnace. Their mean age was 36 (range 19 to 54) years. Their mean working period was 10 years (range 1 to 28). The maximum atmospheric lead content in their working area was $3.38 \mathrm{mg} / \mathrm{m}^{3}$. Two of these workers who had complained of arthralgia were moved from their working shop just after this examination. All the subjects participated voluntarily.

\section{Sampling}

All the blood samples were collected from the antecubital vein, put into heparinized tubes, and the tubes were placed in a jar with Dry Ice immediately. Blood was collected from the subjects in the laboratory for Group $\mathrm{A}$ and in the medical office of the factories for Groups B and C.

\section{Analyses}

Measurement of ALAD activity in blood. Determination of ALAD activity in blood was started within $4 \mathrm{hr}$ after sampling, because the activity fell slightly even on Dry Ice if blood was kept till the next day. (a) Reagents: Buffer $-0.5 \mathrm{~mol} / l$ phosphate buffer $(\mathrm{pH}$ 7.4) was made from monopotassium and disodium phosphate. Substrate solution-100 mg of 5-aminolevulinic acid (ALA) was dissolved in $3 \mathrm{ml}$ of the buffer and $4 \mathrm{ml}$ of $0.1 \mathrm{~mol} / l$ potassium hydroxide $(86 \mathrm{mmol} / \mathrm{l}$ ALA). This solution was prepared fleshly just before using. Modified Ehrlich reagent-1 $\mathrm{g}$ of $\mathrm{p}$-dimethylaminobenzaldehyde was dissolved in the mixture of $42.8 \mathrm{ml}$ of glacal acetic acid, $7.7 \mathrm{ml}$ of $70 \%$ perchloric acid, $2.5 \mathrm{ml}$ of 0.2 $\mathrm{mol} / \mathrm{l}$ mercury dichloride, and $2.5 \mathrm{ml}$ of conc-hydrochloride. TCA-5\% trichloroacetic acid (b) Procedure: $0.1 \mathrm{~m} l$ of buffer and $0.1 \mathrm{~m} l$ of substrate solution were added to $0.2 \mathrm{ml}$ of blood hemolyzed on Dry Ice, and the mixture was incubated at $38^{\circ} \mathrm{C}$ for $1 \mathrm{hr}$. 


\section{ALAD ACTIVITY TO EVALUATE LEAD EXPOSURE}

To stop the reaction, $2 \mathrm{ml}$ of TCA was added to the samples. After centrifugation (3000 $\mathrm{rpm}, 10 \mathrm{~min}$ ), $3 \mathrm{ml}$ of Ehrlich reagent was added to $1 \mathrm{ml}$ of supernatant. After $15 \mathrm{~min}$ accurately, optical densiy (OD) at $556 \mathrm{~nm}$ was read. Each measurement, both with and without heat treatment, was carried out in duplicates.

Heat treatment. This step was a key point of this procedure. Hemolysate containing the buffer solution was shaken for $5 \mathrm{~min}$ in a $60^{\circ} \mathrm{C}$ water bath.

Measurement of $\mathrm{Pb}-\mathrm{B}$. After ashing about $10 \mathrm{~g}$ of blood by the wet technigue and dithizone-methyl isobutyl ketone extraction, $\mathrm{Pb}-\mathrm{B}$ was determined by atomic absorption spectrophotometry.

\section{Calculations}

$\mathrm{ALAD}$ activity $\left[\mu \mathrm{mol} \mathrm{PBG} \cdot \mathrm{h}^{-1} \cdot(\mathrm{m} l \mathrm{RBC})^{-1}\right]=\frac{\mathrm{OD} \text { (sample)-OD (blank) }}{6.2 \times 10^{4}} \times 10^{6} \times 48$ $\times \frac{100}{\mathrm{Ht}} \times 10^{-3}=\frac{\mathrm{JOD}}{\mathrm{Ht}} \times 77$ where $\mathrm{Ht}$ is the hematocrit value, $6.2 \times 10^{4}$ is molar absorbance of porphobilinogen ( $\mathrm{PBG}$ ) (liter $\cdot \mathrm{mol}^{-1} \cdot \mathrm{cm}^{-1}$ ), 48 is the dilution factor of the sample blood. OD (blank) may be negligible because the value is below 0.005 in most cases.

Activity ratio $=\frac{\mathrm{OD} \text { of the sample without heat treatment }}{\mathrm{OD} \text { of the sample activated with heat treatment }}$

\section{RESUlTS}

Fig. 1 shows the mean value and standard deviation (SD) of blood ALAD activity, activity ratio, and $\mathrm{Pb}-\mathrm{B}$ for each group. In three parameters, the differences were statis-

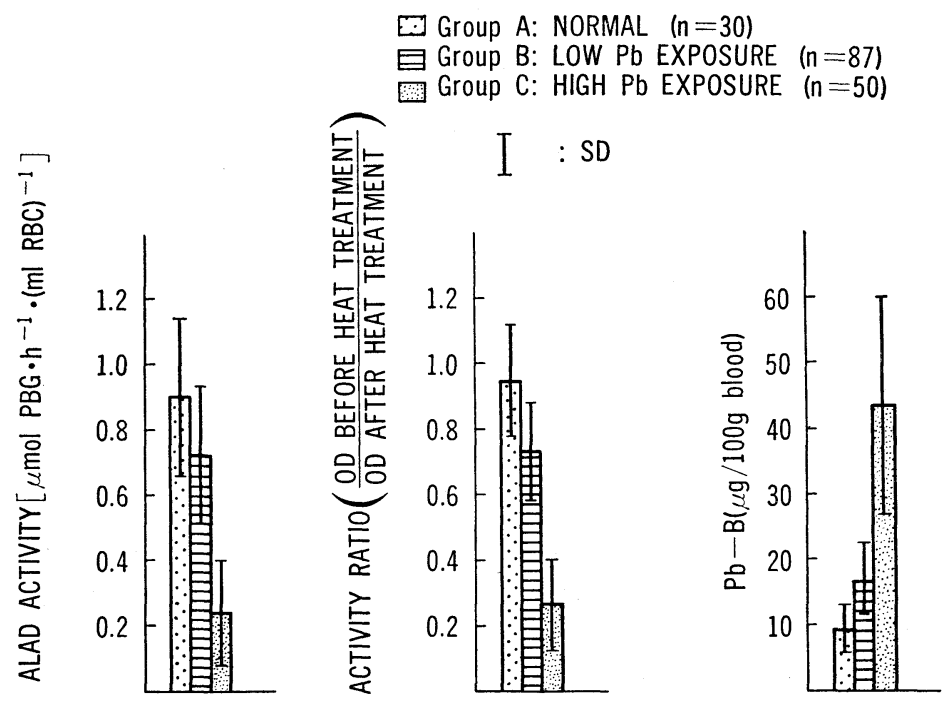

Fig. 1. Mean values of three parameters for each group. 


\section{CHIBA, A. TASHIRO, T. NISHIMA \& M. KIKUCHI}

tically significant between Group A (control) and the others $(p<0.001)$, and between Group B and Group C. Table 1 shows that all subjects are rearranged according to $\mathrm{Pb}-\mathrm{B}$ values independent of their groups. Fig. 2 shows the relationship between blood ALAD activity and $\mathrm{Pb}-\mathrm{B}$. The points from Group $\mathrm{C}$ scattered holizontally at right side of the graph. Fig. 3 shows the relationship between the activity ratio and $\mathrm{Pb}-\mathrm{B}$. The ratio in Group $\mathrm{A}$ is above 0.6 and most of Group $\mathrm{C}$ is under 0.4. It is evident from Figs. 2 and 3 that a certain value of ALAD activity corresponds to a relatively wide $\mathrm{Pb}-\mathrm{B}$ levels rather than to the activity ratio. Furthermore, correlation coefficient between $\mathrm{Pb}-\mathrm{B}$ and the activity ratio $\left(\mathrm{r}_{1}=-0.874\right)$ is higher than that between $\mathrm{Pb}-\mathrm{B}$ and the ALAD activity $\left(r_{2}=-0.768\right)$.

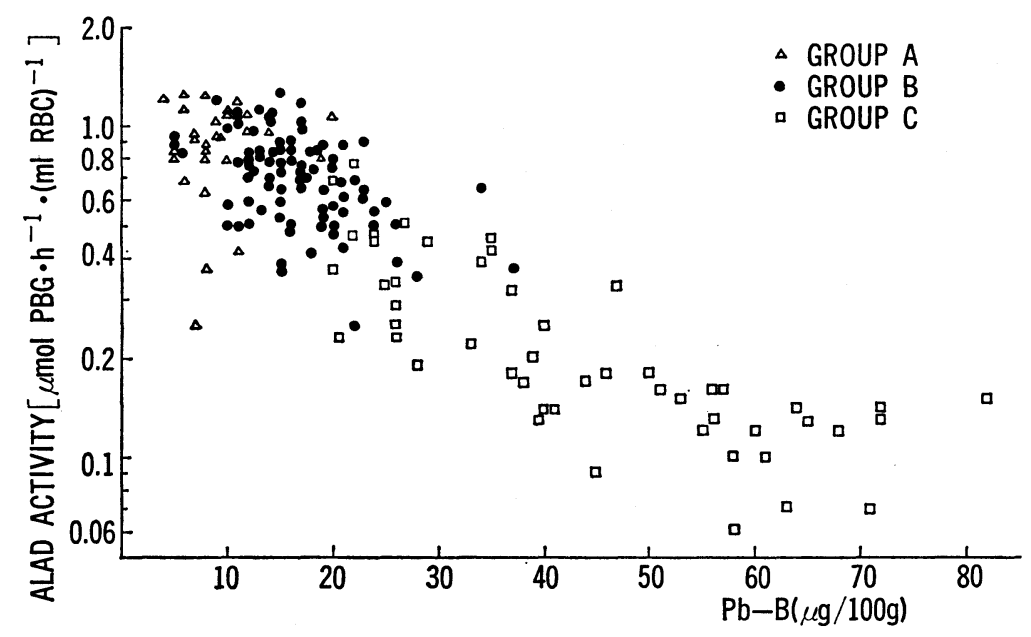

Fig. 2. Relationship between blood $\mathrm{ALAD}$ activity and $\mathrm{Pb}-\mathrm{B}$.

Table 1. Blood ALAD activities before and after heat treatment and activity ratios in different $\mathrm{Pb}-\mathrm{B}$ groups in all subjects.

(A) Grouping at $\mathrm{Pb}-\mathrm{B}$ levels of $20 \mu \mathrm{g} / 100 \mathrm{~g}$ blood.

\begin{tabular}{|c|c|c|c|c|c|c|c|c|c|c|}
\hline \multirow{2}{*}{\multicolumn{2}{|c|}{$\mathrm{Pb}-\mathrm{B}$}} & \multirow{2}{*}{$\begin{array}{l}\text { No. } \\
\text { of } \\
\text { Sub- } \\
\text { jects }\end{array}$} & \multicolumn{2}{|c|}{$\begin{array}{l}\text { ALAD activity } \\
\text { before heating }\end{array}$} & \multicolumn{2}{|c|}{$\begin{array}{l}\text { ALAD activity } \\
\text { after heating }\end{array}$} & \multicolumn{2}{|c|}{ Activity ratio } & \multicolumn{2}{|c|}{ Correlation coefficient } \\
\hline & & & mean & $\mathrm{SD}$ & mean & $\mathrm{SD}$ & mean & $\mathrm{SD}$ & vs. Activity & vs. Ratio \\
\hline & $<20$ & 93 & 0.81 & 0.23 & 0.97 & 0.21 & 0.83 & 0.16 & $-0.226 t$ & $-0.680 \mathrm{tt}$ \\
\hline $20 \leqq$ & $<40$ & 48 & 0.48 & 0.21 & 0.97 & 0.20 & 0.48 & 0.16 & $-0.571 \mathrm{tt}$ & $-0.749 t t$ \\
\hline $40 \leqq$ & $<60$ & 16 & 0.16 & 0.06 & 0.88 & 0.17 & 0.18 & 0.05 & -0.404 & -0.478 \\
\hline $60 \leqq$ & $\leqq 82$ & 10 & 0.12 & 0.03 & 0.92 & 0.13 & 0.13 & 0.03 & -0.394 & +0.148 \\
\hline
\end{tabular}

(B) Grouping into two groups of below $20 \mu \mathrm{g} / 100 \mathrm{~g}$ of $\mathrm{Pb}-\mathrm{B}$.

\begin{tabular}{|c|c|c|c|c|c|c|c|c|c|c|}
\hline & $<10$ & 24 & 0.89 & 0.24 & 0.89 & 0.21 & 1.00 & 0.13 & -0.050 & $-0.506 \pi$ \\
\hline $10 \leqq$ & $<20$ & 69 & 0.78 & 0.22 & 1.00 & 0.20 & 0.78 & 0.13 & -0.205 & $-0.427 \mathrm{tt}$ \\
\hline
\end{tabular}

$\dagger \mathrm{p}<0.05$

$+\mathrm{p}<0.01$ 
ALAD ACTIVITY TO EVALUATE LEAD EXPOSURE

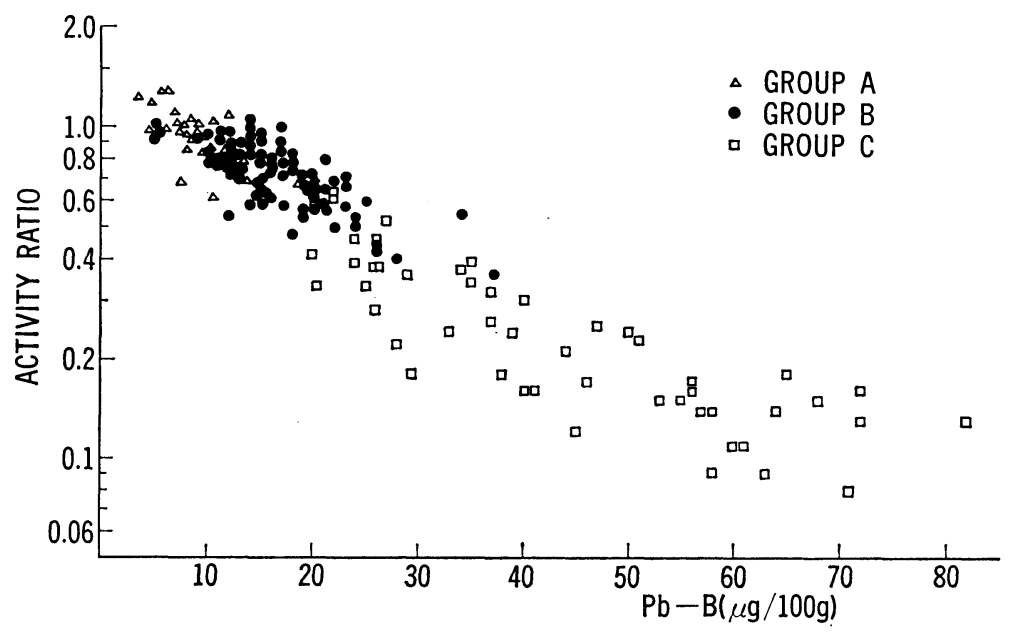

Fig. 3. Relationship between activity ratio and $\mathrm{Pb}-\mathrm{B}$.


Fig. 4. Frequency distribution of ALAD activity before and after heat treatment and activity ratio for each group. 


\section{CHIBA, A. TASĩIRO, T. NISHIMA \& M. KIKUCHI}

Assuming simple Michaelis-Menten kinetics of the non-competitive inhibition type for lead in vivo, inhibitor constant (Ki) may be calculated from the following fomula:

$$
\frac{\mathrm{V}}{\mathrm{Vi}}=1+\frac{1}{\mathrm{Ki}}[\mathrm{Pb}]
$$

where $\mathrm{V}$ is the maximum velocity of this enzyme without an inhibitor, which represents the enzyme activity after heat treatment, and $\mathrm{Vi}$, the velocity in the presence of an inhibitor, which represents the activity before heat treatment. If reciprocal of the ratio is plotted on the ordinate against $\mathrm{Pb}-\mathrm{B}$ on the abscissa, as in Fig. 3, the apparent $\mathrm{Ki}$ is expressed as $1 /$ slope of a regression line. Calculated value of $\mathrm{Ki}$ was $0.4 \mu \mathrm{mol} / \mathrm{liter}$.

Fig. 4 is a histogram of frequency distribution of blood ALAD activities, activities after heat treatment, and the calculated ratios. As is generally known, blood ALAD activity fell markedly as the $\mathrm{Pb}-\mathrm{B}$ level increased (upper column). On the other hand, the activities after heat treatment lie in a relatively same range independent of lead exposure. While the range of ALAD activities of control group was relatively wide,

Table 2. Relationship among $\mathrm{Pb}-\mathrm{B}$, blood $\mathrm{ALAD}$ activity, and activity ratio.

\begin{tabular}{cccc}
\hline Group & $\begin{array}{c}\mathrm{Pb}-\mathrm{B} \\
(\mu \mathrm{g} / 100 \mathrm{~g} \text { blood })\end{array}$ & $\begin{array}{c}\text { ALAD } \\
\text { activity }\end{array}$ & $\begin{array}{c}\text { Activity } \\
\text { ratio }\end{array}$ \\
\hline A & 6 & 0.68 & 0.99 \\
$\mathrm{~A}$ & 8 & 0.63 & 0.85 \\
$\mathrm{~B}$ & 10 & 0.58 & 0.78 \\
$\mathrm{~B}$ & 12 & 0.59 & 0.76 \\
$\mathrm{~B}$ & 14 & 0.69 & 0.67 \\
$\mathrm{~B}$ & 14 & 0.67 & 0.58 \\
$\mathrm{~B}$ & 15 & 0.64 & 0.65 \\
$\mathrm{~B}$ & 15 & 0.59 & 0.63 \\
$\mathrm{~B}$ & 17 & 0.68 & 0.71 \\
$\mathrm{~B}$ & 17 & 0.65 & 0.70 \\
$\mathrm{~B}$ & 19 & 0.65 & 0.67 \\
$\mathrm{~B}$ & 20 & 0.68 & 0.57 \\
$\mathrm{~B}$ & 20 & 0.58 & 0.61 \\
$\mathrm{C}$ & 20 & 0.69 & 0.59 \\
$\mathrm{~B}$ & 21 & 0.61 & 0.57 \\
$\mathrm{~B}$ & 22 & 0.69 & 0.70 \\
$\mathrm{~B}$ & 23 & 0.64 & 0.66 \\
$\mathrm{~B}$ & 23 & 0.60 & 0.57 \\
$\mathrm{~B}$ & 25 & 0.60 & 0.59 \\
$\mathrm{~B}$ & 34 & 0.65 & 0.54 \\
\hline
\end{tabular}

The subjects with 0.58 to $0.69 \mu \mathrm{mol} \mathrm{PBG} \cdot \mathrm{h}^{-1} \cdot(\mathrm{m} l \mathrm{RBC})^{-1}$ of blood ALAD activity are listed in the order of $\mathrm{Pb}-\mathrm{B}$ levels

$\mathrm{r}_{s 1}$ (between $\mathrm{Pb}-\mathrm{B}$ and $\mathrm{ALAD}$ activity) $=-0.042(\mathrm{NS})$

$\mathrm{r}_{82}$ (between $\mathrm{Pb}-\mathrm{B}$ and activity ratio) $=-0.689(\mathrm{p}<0.01)$ 


\section{ALAD ACTIVITY TO EVALUATE LEAD EXPOSURE}

that of the ratio was considerably narrower. A few persons are sometimes found in non-exposed group whose ALAD activity is so low as to suggest lead exposure. These can be distinguished from lead-exposed group by using their activity ratio (upper left and lower left). The availability of the activity ratio will be mentioned in detail later (Table 2).

There was no correlation between the blood ALAD activity or the activity ratio and age or duration of lead exposure of subjects in both Groups B and C.

\section{Discussion}

There are several reports that blood ALAD activity which was reduced by lead in vivo can be increased by some in vitro treatments. For this purpose, Bonsignore et al.,2) Candura et al.,4) Vergnano et al.,3) and Chiba' ${ }^{6)}$ adopted heat treatment of hemolyzed blood samples, Nikkanen et al., ${ }^{7}$ and Tomokuni ${ }^{8)}$ made use of assays at various $\mathrm{pH}$, and Lichtman and Feldman, ${ }^{1}$ Hopke and Prigge,9" and Granick et al. ${ }^{10)}$ added sulfhydryl reagent such as glutathione or dithiothreitol to hemolyzed samples. Tomokuni ${ }^{8}$ and Granick et al. ${ }^{10)}$ proposed an activity ratio calculated from values obtained by two different assays as one of the indices for lead exposure. According to Tomokuni, ${ }^{8)}$ blood ALAD activity itself is better than the activity ratio $(\mathrm{pH})$ in relation to correlation coefficient against $\mathrm{Pb}-\mathrm{B}$, and restoration of the activity by $\mathrm{pH}$ shift is incomplete. In the ratio $(\mathrm{SH})$ by Granick et al.,10) some points agree with our results, although the way of activation employed is different. Points of agreement are (1) restoration of the activity with the $\mathrm{SH}$ reagent treatment is complete, and the blood ALAD activities after activation are about $1 \mu \mathrm{mol} \mathrm{PBG} \cdot \mathrm{h}^{-1} \cdot(\mathrm{m} l \mathrm{RBC})^{-1}$, (2) distribution of each subject's ratio against $\mathrm{Pb}-\mathrm{B}$ value is narrower than that of the activity itself under $50 \mu \mathrm{g} / \mathrm{dl}$, (3) the borderline of the ratio between lead-exposed and non-exposed subjects is about 0.5 , or reciprocal $200 \%$, and (4) the calculated inhibitor constant $(\mathrm{Ki})$ is $0.4 \mu \mathrm{mol} /$ liter.

In Table 1, we consider that the so-called normal value of the blood ALAD activity is above $0.58 \mu \mathrm{mol} \mathrm{PBG} \cdot \mathrm{h}^{-1} \cdot(\mathrm{m} l \mathrm{RBC})^{-1}$ by our method. This is based on the mean value minus $\mathrm{SD}$ of $\mathrm{ALAD}$ activity of blood samples with $\mathrm{Pb}-\mathrm{B}$ below $20 \mu \mathrm{g} / 100 \mathrm{~g}$ which is the $\mathrm{Pb}-\mathrm{B}$ range of non-exposed subjects. Since the mean value plus $\mathrm{SD}$ of the activity, for the subjects with $\mathrm{Pb}-\mathrm{B}$ of 20 to $40 \mu \mathrm{g} / 100 \mathrm{~g}$, in which range the activity decreases lineally, is $0.69 \mu \mathrm{mol} \mathrm{PBG} \cdot \mathrm{h}^{-1} \cdot(\mathrm{ml} \mathrm{RBC})^{-1}$, the subjects whose $\mathrm{Pb}-\mathrm{B}$ values are beyond those of non-exposed ones may be included in the group of 0.58 to $0.69 \mu \mathrm{mol} \mathrm{PBG} \cdot \mathrm{h}^{-1}$. $(\mathrm{m} l \mathrm{RBC})^{-1}$ of the ALAD activities. Our activity ratio is useful in distinguishing them as shown in Table 2 , in which cases with 0.58 to $0.69 \mu \mathrm{mol} \mathrm{PBG} \cdot \mathrm{h}^{-1} \cdot(\mathrm{m} l \mathrm{RBC})^{-1}$ of blood $\mathrm{ALAD}$ activity are listed in the order of their $\mathrm{Pb}-\mathrm{B}$ values. The rank correlation coefficients were calculated between $\mathrm{Pb}-\mathrm{B}$ and the activity itself $\left[\mathrm{r}_{s 1}=-0.042(\mathrm{NS})\right]$, and between $\mathrm{Pb}-\mathrm{B}$ and activity ratio, $\mathrm{r}_{s 2}=0.689(\mathrm{p}<0.01)$. This reveals that the activity ratio reflects $\mathrm{Pb}-\mathrm{B}$ level better than the activity itself. Other advantages of using our ratio are (1) while the activity cannot be compared unless the assay methods are 


\section{CHIBA, A. TASHIRO, T. NISHIMA \& M. KIKUCHI}

same, the ratios are comparable without such consideration, and (2) the ratio shows a close negative correlation against $\mathrm{Pb}-\mathrm{B}$ rather than the activity itself as mentioned above. We considered that the reasone for the latter is because individual variation may be eliminated by divison of the activities by the values with and without heat treatment, by which the effect of lead on the organisms remains. The disadvantage of this ratio is that when $\mathrm{Pb}-\mathrm{B}$ is over $40 \mu \mathrm{g} / 100 \mathrm{~g}$ blood the correlation between the ratio and $\mathrm{Pb}-\mathrm{B}$ becomes weaker as the activity itself. Perhaps, the blood ALAD activity is extremely sensitive to lead and its fall reaches the lowest at about $40 \mu \mathrm{g} / 100 \mathrm{~g} \mathrm{~Pb}-\mathrm{B}$.

We made a hypothesis for the explanation of the activity change after heat treatment. ALAD in blood includes at least two components ${ }^{6}$; the one is inherently active and is inhibited by heat treatment and lead in vivo, and the other is inherently inactive at a lower temperature and is activated by heat treatment and stable to lead in vivo. On the other hand, Dingeon and Rullet ${ }^{11}$ has considered that two enzyme fractions were present in blood, which had $\mathrm{pH}$ optimum of 6.8 and 6.1. This interesting problem deserves further elucidation.

\section{ACKNOWLEDGEMEnT}

We wish to thank Dr. Yoshihisa Nishino and Dr. Kunio Abe of the Departments of Internal Medicine and Anatomy, Juntendo University for making it possible to study the factory workers, and Miss Setsuko Tsukidate for her technical assistance.

\section{REFERENCES}

1) Lichtman, H. C. and Feldman, F. (1963). J. Clin. Invest., 42, 830.

2) Bonsignore, D., Cartasegna, C. and Vergnano, C. and Aldoino, V. (1968). Med. Lav., 59, 419.

3) Vergnano, C., Cartasegna, C. and Ardoino, V. (1969). Med. Lav., 60, 505.

4) Candura, F., Franco, G. and Pozzi, U. (1971). Lav. Um., 23, 1.

5) Chiba, M. and Kikuchi, M. (1973). Jap. J. Ind. Health, 15, 656. (in Japanese)

6) Chiba, M. (1976). Brit. J. Ind. Med., 33, 36.

7) Nikkanen, J., Hernberg, S. and Tola, S., (1972). Work. Environ. Health, 9, 46.

8) Tomokuni, K. (1974). Arch. Environ. Health, 29, 274.

9) Hapke, H. J. and Prigge, E. (1973). Arch. Toxicol., 31, 153.

10) Granick, J. K., Sassa, S., Granick, S., Levere, R. D. and Kappas, A. (1973). Biochem. Med., $8,149$.

11) Dingeon, B. and Roullet, A. (1975). Arch. Environ. Health, 30, 317. 